\title{
Genç Sporcu ve Antrenörlerde Sigara İçme Alışkanlık ve Davranışları
}

\author{
The Prevalence of Smoking and Attitudes toward Smoking among Young \\ Athletes and Coaches
}

\author{
Hüseyin ASLAN* \\ Kenan ERDAĞI** \\ Bülent IŞIK*** \\ Mükerrem ERDOĞAN ${ }^{* * * *}$ \\ Alpay GÜVENÇ*****
}

Öz: Bu çalışmanın amacı, genç sporcu ve antrenörlerde sigara içme alışkanlığının ve sigara içme davranışını etkileyen değişkenlerin incelenmesidir. Araştırma, Konya'da 2016 yılında düzenlenmiş olan Türkiye Gençler Halter Şampiyonası sırasında gerçekleştirilmiştir. Toplam 225 katılımcıdan sigara kullanımına ilişkin tutum ve davranışlarıyla birlikte, demografik özelliklerine yönelik veriler anket yardımıyla toplanmıştır. Verilerin analizi Ki-kare testi ile yapılmıştır. Genç yarışmacı sporcu ve antrenörlerde sigara içme sıklığı \%33.8 olarak belirlenmiş̦tir. Özellikle genç sporcularda sigaraya başlama yaşının $13.8 \pm 2.4$ yıl gibi oldukça erken bir dönem olduğu tespit edilmiştir. Sigara içen genç sporcu ve antrenörlerin yaklaşık olarak \%60'ının günde 10 adetten fazla sayıda sigara içtiği ve bu alışkanlığa sportif kariyer öncesinde başladığı belirlenmiştir. Sigara içen olgulardan $\% 81.6$ 's1 en az 2 yıl ve daha uzun süredir sigara içmeyi sürdürmektedir. Ayrıca, sigara içen genç sporcu ve antrenörlerin \%61.8'inin sigarayı bırakmak istediği, \%63.2'sinin bırakmayı denediği, ancak başaramadığı ve \%81.6'sının herhangi bir sigara bıraktırma eğitimine katılmadığı belirlenmiştir. Özellikle, sigara içmenin performansı olumsuz yönde etkilemeyeceğini ve sporcunun sigara içebileceğini düşünen olguların daha fazla oranda sigara içme davranışı sergilediği gözlenmiştir. Sonuç olarak, genç sporcu ve antrenörlerde sigara içme sıklığının oldukça yüksek olmasından dolayı, toplumda rol model olan sporcu ve antrenörlere yönelik, özellikle sigaranın performans üzerindeki olumsuz etkilerinin vurgulandığı, sigara bıraktırma eğitimlerinin önemli olduğu anlaşılmaktadır.

Anahtar sözcükler: Sigara Alışkanlığı, Genç Sporcular, Antrenörler, Fiziksel Performans, Sağlık

Abstract: The aim of this study was to investigate smoking habits and attitudes toward smoking among young competitive athletes and coaches. This study was conducted during the 2016 Youth National Weightlifting Championships held at Konya. Data was collected from a total of 225 subjects through using a questionnaire including demographics, as well as behaviors and attitudes related to smoking. The prevalence of smoking was $33.8 \%$ and the mean age of the onset of smoking was $14.6 \pm 3.3$ years, with young athletes having started smoking as early as $13.8 \pm 2.4$ years of age. Nearly $60 \%$ of smokers reported smoking at least 10 cigarettes/day and started their habit before the start of their athletic careers. It was determined that $81.6 \%$ of smokers had a history of smoking for at least 2 years or more. Furthermore, $61.8 \%$ of smokers wanted to quit smoking, $63.2 \%$ had attempted to quit but failed and $81.6 \%$ of them didn't participate in any smoking cessation program. Notably, those subjects who stated that their performance was not negatively affected by smoking, had significantly more smoking behaviors than others. Given the high smoking prevalence amongst young athletes and coaches as role models in society, the current results highlight the importance of smoking cessation programs that are addressed to them.

Keywords: Smoking, Young Athletes, Coaches, Physical Performance, Health

\footnotetext{
* PhD., Öğr.Gör., Selçuk Üniversitesi, Spor Bilimleri Fakültesi, Konya. huseyinarslan@selcuk.edu.tr

** PhD., Gençlik Hizmetleri ve Spor İl Müdürlügü, Konya. kenanerdal@hotmail.com

**** PhD., Hekim, İl Sağlık Müdürlüğ̈̈, Konya. drbulent42@gmail.com

**** PhD., Öğr.Gör., Akdeniz Üniversitesi, Sağlık Hizmetleri Meslek YO., Antalya. mukerremerdogan@akdeniz.edu.tr

****** Doç. Dr., Akdeniz Üniversitesi, Spor Bilimleri Fakültesi, Antenörlük Eğitimi Böl., Antalya. guvenc@akdeniz.edu.tr
} 
Sigara içme alışkanlığı dünyada önlenebilir ölüm nedenlerinin en yaygınıdır. Her sekiz saniyede bir insan sigaradan kaynaklanan hastalıklar nedeniyle ölmektedir (Alışkın 2015). Bu kötü alışkanlık bir yetişkin bağımlılığı gibi değerlendirilse de aslında, genç insanların kendi özgürlük duygularını ispatlayabilmek için başlayan heveslerinin zamanla tütün ürünlerine karşı bağımlılık olarak devam etmesini de kapsamaktadır. Sigara içmeye başlama yaşının ilkokul dönemlerine kadar düştüğü ülkemizde, özellikle 20 yaştan küçük gençlerin ilk içiciliğe arkadaş ortamı, sosyal çevre, merak, arzu ve özenti gibi önlenebilir nedenlerle başladığı görülmektedir (Sağlam 2000).

Sigara dumanı içinde bazıları farmakolojik olarak aktif, antijenik, sitotoksik, mutajenik ve karsinojenik olan 4.000' den fazla zehirli madde vardır. Bu zehirlerin büyük kısmı gaz fazında olup solunabilir düzeydedir (Behr \& Nowak 2002). Sigara dumanında bulunan ve 8 saniye içinde beyne etki edebilen nikotin beyinde keyif verici kimyasalların salgılanmasına ve kısa bir süre için kendini iyi hissetmeye yol açar. Uzun süre sigara içenlerde bir takım kimyasal değişikliklere bağlı olarak beynin nikotinle uyarılma ihtiyacı artar. Nikotin, eroin veya kokain gibi beynin çalışma şeklini değiştirir ve daha çok nikotin istemesine neden olur. Nikotine olan bu bağımlılık sigara veya diğer tütün ürünlerini bırakmayı zorlaştırır. Sigara bırakma sürecinde iradeyi zorlayacak olan, nikotine ihtiyaç hissidir (Kanıt \& Keser 2010).

Türkiye kişi başına sigara tüketimi yönünden Avrupa ülkeleri arasında Yunanistan'dan sonra ikinci sırada dünya tütün üretiminde ise beşinci sırada yer almaktadır (Erbaycu 2004; Öztürk 2009). Gelişmekte olan ülkelerde sigaraya başlama 12 ile 16'l1 yaşlar arasında olmaktadır. Her gün dünyada 80.000-100.000 arasında genç tütün bağımlısı haline gelmektedir. Dünya sağlık örgütüne göre bir salgın olan sigara bağımlılığ 1 "düzenli olarak günde bir sigara içme” olarak tanımlanmaktadır (Aşut 1993). Gelişmiş ülkelerde 13-15 yaşları arasındaki gençlerde sigara içme sıklığ $\% 10$ ile \%33 arasında değişmektedir (Karlıkaya 2006). Sağlık Bakanlığ 2015 sağlık istatistikleri yıllığında Türkiye İstatistik Kurumu verilerine göre ülkemizde halen tütün mamulü kullananların tütün mamulüne ilk başlama yaşı olarak; \%23.1 oranında 10-14 yaş, \%47.8 oranında 15-19 yaş gösterilmiştir. Ülkemizde her gün tütün mamulü kullanma sıklığı 2012'de ortalama \%23.2 (erkeklerde; \%35.9, kadınlarda; \%10.8) olarak hesaplanmıştır (Sağlık İstatistikleri 2015).

Sigara içenler içmeyenlere göre daha yüksek sıklıkta hastalanmaktadırlar. Sigara içenlerin içmeyenlere göre akut ve kronik bir hastalığa yakalanma oranları daha fazladır. Ergenlik döneminde sigaraya başlayan kişilerde beklenen yaşam süresi içmeyenlerle karşılaştırıldığında 2025 yıl daha kısadır (Peto 1994). Sigara içmek, başta kanser, koroner kalp hastalığı ve kronik obstrüktif akciğer hastalı̆̆ gibi 20'ye yakın ölümcül hastalıkla ve direkt ölümle sonlanmayan yaklaşık 50 kadar kronik hastalıkla ilişkili bulunmuştur (Ash 2016).

Sigara içmek tüm toplumda olduğu gibi sporcularda da pek çok ölümcül hastalığa sebep olmasının yanında, gerek aktif spor yaşamını kısaltması, gerekse fiziksel performans kayıplarına sebep olması nedeniyle önemli bir sorundur (Feinberg 2015). Sigara içme alışkanlığıyla mücadele etmenin odak noktası, gençlerin sigaraya karşı dirençli hale getirilmesi ve onların sigaraya başlamasının önlenmesidir. Çünkü gençlerin sigara kullanmaya başlamaması, sorunları önceden önlemek anlamını taşır ve kendilerini ve tüm toplumu kurtarıcı niteliktedir (Breslau \& Peterson 1996).

Diğer taraftan, sporcular üzerinde önemli rol model özelliği olan antrenörlerin ve yarışmacı genç lider sporcuların sigara içme davranışında artışın önlenmesi ve sigarayla mücadele konusunda büyük sorumlulukları vardır. Bu yüzden gerek sporcularda gerekse antrenörlerde sigara içme alışkanlık ve davranışının bilimsel araştırmalarla ortaya konulması ve incelenmesi oldukça önemlidir. İlgili literatür incelendiğinde, farklı spor dallarındaki sporcularda sigara içme 
alışkanlığının değerlendirildiği bazı araştırmalar bulunmaktadır (Arıkan \& Şanlıer 2006; Hessami 2012; Pacifici 2016). Ancak mevcut literatürde sigara içme alışkanlığı ve davranış1 ile ilgili olarak halter spor dalı özelinde genç yarışmacı sporculara yönelik olarak yapılmış herhangi bir araştırma bulunmamaktadır. Bu araştırma bu yönü ile bir ilk olacaktır. Ülkemizde ve tüm dünyada yaygın bir bireysel spor dalı olan halter ile uğraşan genç sporcu ve antrenörlerin sigara içme alışkanlık ve davranışlarının değerlendirildiği bu çalışma mevcut literatüre katkı sağlayacaktır. Buradan hareketle bu çalışmanın amacı, genç yarışmacı halter sporcuları ve antrenörlerde sigara içme alışkanlığının değerlendirilmesi ve sigara içme davranışını etkileyebilecek durum, görüş ve tutumların incelenmesidir.

\section{Yöntem}

\section{Araştırma Grubu}

Bu araştırmaya 201 'i genç halter sporcusu ve 24'ü antrenör olmak üzere toplam 225 yarışmacı sporcu ve antrenör gönüllü olarak katılmıştır. Araştırma grubunun yaş ortalaması $18.5 \pm 5.9$ yıl $(\mathrm{n}=225)$ olarak belirlenmiştir. Bununla birlikte, araştırma grubu içerisindeki halter sporcularının yaş ortalaması $16.9 \pm 2.8$ yıl $(\mathrm{n}=201)$ olarak belirlenirken, antrenörlerin yaş ortalaması $32.0 \pm$ 8.2 yıl $(\mathrm{n}=24)$ olarak kaydedilmiştir. Ayrıca, araştırma grubu içerisinde yer alan genç sporcularının en az bir yıl olmak üzere, ortalama $3.6 \pm 2.8$ yıl süresince düzenli olarak antrenman yaptığı ve yarışmacı düzeyde halter branşıla uğraştığı tespit edilmiştir. Yine araştırma grubunu oluşturan antrenörlerin ise ortalama olarak $9.2 \pm 7.6$ yıl süresince bu spor dalında aktif antrenörlük deneyimleri vardır.

\section{Araştırma Düzeni ve Verilerin Toplanması}

Araştırma popülasyonunu Türkiye Halter Federasyonu tarafından 24-26 Nisan 2016 tarihleri arasında Konya ilinde düzenlenen Türkiye Gençler Halter Şampiyonası'na katılan genç halterci ve antrenörler oluşturmaktadır. Bu araştırma kesitsel nitelikte bir anket çalışmasıdır. Toplam 41 sorudan oluşan anket, halter federasyonunda lisanslı 334 genç halter sporcusu ve 30 kadar antrenörden oluşan popülasyondan yarışmaya katılan, kendisine ulaşılabilen ve araştırmaya katılmayı gönüllü olarak kabul eden toplam 225 (\%62) katılımcıya yüz yüze görüşme tekniği kullanılarak uygulanmıştır. Araştırmanın verileri, araştırmacılar tarafından literatüre göre hazırlanan, katılımcıların bazı sosyo-demografik özelliklerini belirlemeye yönelik 14 sorudan oluşan kişisel bilgi formu ve sigara kullanımı hakkında tutum ve davranışlarını belirlemeyi hedefleyen 27 sorudan oluşan davranış düzeyi ölçme formu aracılığı ile toplanmıştır (Sezer 2001).

Uygulanan ankette yaş, cinsiyet, eğitim düzeyi, ikamet durumu, medeni durum ve yaşam yeri gibi bazı sosyo-demografik özelliklerin yanı sıra, genç sporcu ve antrenörlerin sigara içme alışkanlıları, sigara içme sıklığı, sigaraya başlama yaşı, günlük tüketilen sigara sayısı, sigara içme geçmişi ve sigaraya karşı çeşitli tutum ve davranışları değerlendirilmiştir. Ayrıca elde edilen verilerden, araştırma grubunda sigara içmeyi bırakan olguların sigara içenler içerisindeki payı "[sigara içmeyi bırakanlar / (sigara içenler + sigara içmeyi bırakanlar)] x 100" eşitliği ile hesaplanmıştır. Araştırmaya katılacak genç sporcu ve antrenörler çalışma konusunda bilgilendirilmiş, araştırma gönüllü katılım esasına göre yapılmış ve katılımcılardan onam alınmıştır.

\section{Verilerin Analizi}

Araştırmada tüm değişkenlere ilişkin nitelik verilerde frekans (n) ve yüzde (\%) dağılımları, sayısal verilerde ise aritmetik ortalama (X) ve standart sapma (SS) değerleri hesaplanmıştır. Araştırma grubunda farklı sosyo-demografik özelliklere göre sigara alışkanlığı dağılımları ve 
sigaraya ilişkin düşünce ve tutumlara göre sigara alışkanlığı dağılımları Ki-kare Testi ile analiz edilmiştir. İstatistiksel analizler SPSS paket programında yapılmış ve uygulanan tüm istatistiksel işlemlerde $\alpha=0.05$ yanılma düzeyi dikkate alınmıştır.

\section{Bulgular}

Genç sporcular ve antrenörlerin sigara içme alışkanlıkları ve sigara kullanımına ilişkin davranış ve tutumlarını incelemek amacıyla yapılan bu çalışmaya toplam 225 kişi gönüllü olarak katılmıştır. Araştırma grubunu oluşturan genç yarışmacı sporcular ve antrenörlerin bazı sosyo-demografik özellikleri Tablo 1'de verilmiştir.

Tablo 1'de görüldüğü gibi, araştırma grubunun \%68.4'ü erkek, \%31.6's1 ise kadındır. Ayrıca, araştırma grubunu oluşturan olguların büyük bir kısmının bekar olduğu (\%87.6), genellikle şehir merkezinde yaşadıkları (\%88.0) ve siklıkla ailelerinin yanında ikamet ettikleri (\%87.1) ve ebeveynlerinin daha yüksek oranda ilköğretim düzeyinde (baba ve anne sirasıly, \%58.2 ve \%70.2), kendilerinin ise daha yüksek oranda lise düzeyinde (\%74.7) eğitim durumuna sahip oldukları tespit edilmiştir.

Araştırma grubunu oluşturan genç sporcu ve antrenörlerin sigara içme durumları ve sigaraya ilişkin düşünce ve görüşleri Tablo 2'de yer almaktadır. Buna göre, araştırma grubunda halen sigara içen 76 (\%33.8), hiç sigara içmeyen $128(\% 56.9)$ ve sigara içmeyi bırakan 21 (\%9.3) genç sporcu ve antrenör bulunmaktadır. Bununla birlikte, halen sigara içen 76 olgudan 65’i (\%85.5) sporcu, 11’i (\%14.5) antrenör, hiç sigara içmeyen 128 olgudan 119'u (\%93.0) sporcu, 9'u (\%7.0) antrenör ve sigara içmeyi

Tablo 1. Araştırma Grubuna İlişkin Bazı Sosyo-Demografik Özellikler

\begin{tabular}{|l|c|c|}
\hline & Sayı (n) & Yüzde (\%) \\
\hline Cinsiyet & 154 & 68.4 \\
\hline - Erkek & 71 & 31.6 \\
\hline Eăitım düzeyi & & \\
\hline - İköğretim & 29 & 12.9 \\
\hline - Lise & 168 & 74.7 \\
\hline - Yükseköğretim & 28 & 12.4 \\
\hline Medeni durum & & \\
\hline - Evli & 28 & 12.4 \\
\hline - Bekâr & 197 & 87.6 \\
\hline Baba eğitim düzeyi & & \\
\hline - İköğretim & 131 & 58.2 \\
\hline - Lise & 70 & 31.1 \\
\hline - Yükseköğretim & 24 & 10.7 \\
\hline Anne eğitim düzeyi & & \\
\hline - İköğretim & 158 & 70.2 \\
\hline - Lise & 51 & 22.7 \\
\hline - Yükseköğretim & 16 & 7.1 \\
\hline Yaşam yeri & & \\
\hline - SSehir merkezi & 198 & 88.0 \\
\hline - Kasaba veya köy & 27 & 12.0 \\
\hline İkamet durumu & & \\
\hline - Aile yanı & 196 & 87.1 \\
\hline - Arkadaş yanı veya yurt & 29 & 12.9 \\
\hline
\end{tabular}

bırakan 21 olgudan 17'si (\%81.0) sporcu, 4’ü - Arkadaş yanı veya yurt
(\%19.0) ise antrenördür. Araştırma grubunda halen sigara içen 65 genç sporcunun sigaraya başlama yaşı ortalamaları $13.8 \pm 2.4$ yıl, halen sigara içen 11 antrenörün ise sigaraya başlama yaş1 ortalamaları $18.0 \pm 5.2$ y1l olarak belirlenmiştir. Genel olarak araştırma grubunda halen sigara içen olguların $(n=76)$ sigaraya başlama yaşı ortalamaları $14.6 \pm 3.3$ yıldır. Buradan da anlaşılacağı gibi özellikle araştırma örneklemi içerisindeki genç sporcularda sigara içmeye başlama yaş1 (13.8 \pm 2.4 yıl) oldukça düşüktür. Ayrıca araştırma grubunda sigara içmeyi bırakan 17 sporcu ve 4 antrenörden oluşan toplam 21 olgunun \%64.2'sinin sadece en fazla 1 y1l süresince geçmişte sigara kullandığ 1 ve yine bu 21 olgunun \%90.5'inin sigarayı bırakırken herhangi bir yardım almadığ 1 tespit edilmiştir. Araştırma grubunda sigara içmeyi bırakan olguların sigara içenler içerisindeki payı \%21.6 olarak bulunmuştur. Bu durum araştırma grubunu oluşturan genç sporcu ve antrenörlerde sigara içmeye başladıktan sonra sigara içmeyi bırakabilme oranının oldukça düşük olduğunu göstermesi açısından önemlidir. 
Diğer taraftan Tablo 2'den de anlaş1lacağı gibi araştırma grubundaki olguların \%16.9'u haftada en az iki kere ve daha fazla olmak üzere nargile, pipo veya puro gibi sigara d1şında tütün mamülü kullanmaktadır. Ayrica genç sporcu ve antrenörler en etkili sigara bırakma yöntemi olarak ilk sırada \%28.9 oranında "azaltarak bırakma" yöntemini, ikinci sırada ise $\% 16.0$ oranında "nikotin yerine koy$m a$ " yöntemini gördüklerini belirtmişlerdir. Ancak olguların \%17.8'i en etkili sigara bırakma yöntemi konusunda herhangi bir fikrinin olmadığını belirtmektedir. Diğer taraftan genç sporcu ve antrenörlerin yaklaşık olarak \%21'i antrenman ve maç öncesi veya sonrası sigara içilebileceği düşüncesini benimserken, yaklaşık olarak \%79'u sigara içilmemesi gerektiğini düşünmektedir.

Araştırma grubunda sigara içen sporcu ve antrenörlerin sigara içme alışkanlıkları ve sigaraya ilişkin tutum ve davranışları Tablo 3'de sergilenmiştir.

Tablo 3'den de anlaşılacağ gibi sigara içen genç sporcu ve antre-
Tablo 2. Araştırma Grubunda Sigara İçme Durumu ve Sigaraya İlișkin Düșünce ve Görüșler

\begin{tabular}{|l|c|c|}
\hline & Sayı (n) & Yüzde (\%) \\
\hline Sigara içme durumu & & \\
\hline - Sigara içenler & 16 & 33.8 \\
\hline - Hiç sigara içmeyenler & 21 & 56.9 \\
\hline - Sigara içmeyi bırakanlar & & \\
\hline Sigara dışında tütün kullanımı & 187 & 83.1 \\
\hline - Tütün mamülü kullanmayan & 28 & 12.5 \\
\hline - Nargile içen (haftada 2 ve fazla) & 10 & 4.4 \\
\hline - Pipo, puro içen (haftada 2 ve fazla) & & \\
\hline $\begin{array}{l}\text { Farklı bir iş yapsaydınız sigara } \\
\text { içme durumunuz ne olurdu? }\end{array}$ & & \\
\hline - Daha çok içerdim & 47 & 20.9 \\
\hline - Hiç içmezdim & 149 & 66.2 \\
\hline - Daha az içerdim & 29 & 12.9 \\
\hline $\begin{array}{l}\text { En etkili sigara bırakma yöntemi } \\
\text { sizce nedir? }\end{array}$ & & \\
\hline - Nikotin yerine koyma & 36 & 16.0 \\
\hline - Bireysel psikoterapi & 18 & 8.0 \\
\hline - Grup psikoterapisi & 12 & 5.3 \\
\hline - Akupunktur & 12 & 5.3 \\
\hline - Hipnoz & 17 & 7.6 \\
\hline - Aniden bırakma & 25 & 11.1 \\
\hline - Azaltarak bırakma & 65 & 28.9 \\
\hline - Fikrim yok & 40 & 17.8 \\
\hline $\begin{array}{l}\text { Antrenman ve maç öncesi sigara } \\
\text { içilebilir mi? }\end{array}$ & & \\
\hline - Evet içilebilir & 46 & 20.5 \\
\hline - Hayır içilmemelidir & & 79.5 \\
\hline $\begin{array}{l}\text { Antrenman ve maç sonrası sigara } \\
\text { içilebilir mi? }\end{array}$ & 176 & 78.2 \\
\hline - Evet içilebilir & & \\
\hline - Hayır içilmemelidir & & \\
\hline a & & \\
\hline
\end{tabular}
nörlerin sadece \%40.8'i günde 1 ile 10 adet arasında sigara içmektedir, geriye kalan \%59.2'si ise günde 10 adetten fazla sayıda sigara tüketmektedir. Sigara içen olguların \%81.6'sının en az 2 yıl ve daha uzun süredir sigara içtikleri tespit edilmiştir. Sigara içen genç sporcu ve antrenörlerin \%27.6'sının en az 8 yıl ve daha uzun süredir sigara içmeye devam ettikleri ve \%59.2'sinin spora başlamadan önce sigara içmeye başladıkları belirlenmiştir. Ayrıca, sigara içenlerden \%56.6'sının yasak olan yerlerde sigara içmenin zor olmayacağını belirtmesi ve \%72.4'ünün sigara bittiğinde arkadaşlarından sigara istediğini belirtmiş olması, sigara bağımlılı̆̆ının düzeyini göstermesi açısından önemlidir. Diğer taraftan araştırma grubunda halen sigara içen sporcu ve antrenörlerin \%61.8'i sigarayı bırakmak istediklerini, ancak \%51.3'ü sigarayı bırakabileceğini düşünmediklerini belirtmişlerdir. Yine tablo 3 'de, sigara içen olguların \%63.2'sinin sigarayı bırakmayı denedikleri ancak bunda başarılı olamadıkları ve \%81.6'sının ise sigara bıraktırma eğitimine katılmadıkları dikkate alındığında, gelecekte sporcu ve antrenörlere uygulanacak olan sigara bıraktırma eğitimi programlarının ne kadar önemli olabileceği görülmektedir.

Araştırma grubunu oluşturan genç sporcu ve antrenörlerin cinsiyet, medeni durum, eğitim düzeyi, ebeveyn eğitim düzeyi, yaşam yeri ve ikamet durumlarına göre sigara içme alışkanlıkları tablo 4'de sergilenmiştir. 
Tablo 4'de görüldüğü gibi, araştırma grubundaki erkeklerin \%36.4'ü halen sigara içen, \%55.8'i hiç sigara içmeyen ve \%7.8'i sigara içmeyi bırakanlar grubunda yer almakta, kadınların ise \%28.2'si halen sigara içen, \%59.2'si hiç sigara içmeyen ve \%12.6's1 sigara içmeyi bırakanlar grubunda yer almaktadır. Buradan da anlaşılacağ 1 gibi, genç sporcu ve antrenörlerin sigara içme, sigara içmeme ve sigarayı bırakma davranışları erkek ve kadın olgularda benzer dağılım sergilemekte ve sigara içme durumu cinsiyete göre anlamlı ölçüde değişkenlik göstermemektedir $\left(X^{2}=2.302 ; \mathrm{p}>0.05\right)$. Bununla birlikte, araştırma grubunda sigara içme, sigara içmeme ve sigarayı bırakma davranışları olguların medeni durumlarına $\left(X^{2}=0.513 ; \quad \mathrm{p}>0.05\right)$ ve ebeveynlerinin eğitim düzeyine (baba ve anne sirasıyla, $X^{2}=6.209 ; \mathrm{p}>0.05$ ve $X^{2}=6.156 ; \mathrm{p}>0.05$ ) göre de anlamlı ölçüde değişiklik sergilememektedir. Diğer taraftan, genç sporcu ve antrenörlerin sigara içme durumlar1 eğitim düzeylerine $\left(X^{2}=13.773\right.$; $\mathrm{p}<0.05)$, yaşam yerine $\left(X^{2}=11.272 ; \mathrm{p}<0.05\right)$ ve ikamet ettikleri yere $\left(X^{2}=18.112\right.$; $\mathrm{p}<0.05)$ göre anlamlı ölçüde değişmektedir. Araştırma grubunda eğitim düzeyi ilköğretim olan olguların \%27.6's halen sigara içen, \%51.7'si hiç sigara içmeyen, \%20.7'si sigara içmeyi bırakan durumdayken, eğitim düzeyi lise olan olguların \%33.3'ü halen sigara içen, \%61.3’ü hiç sigara içmeyen ve sadece \%5.4'ü sigara içmeyi bırakan durumundadır. Eğitim düzeyi yükseköğretim olan olguların ise \%42.9'u halen sigara içen, \%35.7’si hiç Tablo 3. Araştırma Grubunda Sigara İçenlerin Sigara İçme Alışkanlıkları ve Sigaraya İlişkin Davranışları

\begin{tabular}{|c|c|c|}
\hline & Sayı (n) & Yüzde (\%) \\
\hline \multicolumn{3}{|l|}{$\begin{array}{l}\text { Günlük tüketilen sigara miktarı } \\
\text { (adet) }\end{array}$} \\
\hline$-1-10$ adet & 31 & 40.8 \\
\hline$-11-20$ adet & 37 & 48.7 \\
\hline - 21-39 adet & 3 & 3.9 \\
\hline-40 adet ve fazlas 1 & 5 & 6.6 \\
\hline \multicolumn{3}{|l|}{ Sigara içme geçmişi (yıl) } \\
\hline$-0-1$ y1l & 14 & 18.4 \\
\hline$-2-3$ yil & 29 & 38.2 \\
\hline$-4-7$ yil & 12 & 15.8 \\
\hline$-8-10$ yıl & 12 & 15.8 \\
\hline-10 yildan fazla & 9 & 11.8 \\
\hline \multicolumn{3}{|l|}{ Sigara içmeye başlama dönemi } \\
\hline - Spora başlamadan önce & 45 & 59.2 \\
\hline - Spora başladıktan sonra & 31 & 40.8 \\
\hline \multicolumn{3}{|l|}{$\begin{array}{l}\text { Sigara içmenin yasak olduğu } \\
\text { yerlerde sigara içmek zor oluyor } \\
\text { mu? }\end{array}$} \\
\hline - Evet zor oluyor & 33 & 43.4 \\
\hline - Hayır zor olmuyor & 43 & 56.6 \\
\hline \multicolumn{3}{|l|}{$\begin{array}{l}\text { Sigaranız biterse } \\
\text { arkadaşlarınıdan sigara ister } \\
\text { misiniz? }\end{array}$} \\
\hline - Evet isterim & 55 & 72.4 \\
\hline - Hayır istemem & 21 & 27.6 \\
\hline \multicolumn{3}{|l|}{ Sigarayı bırakmak ister misiniz? } \\
\hline - Evet isterim & 47 & 61.8 \\
\hline - Hayır istemem & 29 & 38.2 \\
\hline \multicolumn{3}{|l|}{$\begin{array}{l}\text { Sigarayı bırakmayı denediniz } \\
\text { mi? }\end{array}$} \\
\hline - Evet denedim ama başaramadım & 48 & 63.2 \\
\hline - Hayır denemedim & 28 & 36.8 \\
\hline \multicolumn{3}{|l|}{$\begin{array}{l}\text { Sigarayı bırakabileceğinizi } \\
\text { düşünüyor musunuz? }\end{array}$} \\
\hline - Evet & 37 & 48.7 \\
\hline - Hayır & 39 & 51.3 \\
\hline \multicolumn{3}{|l|}{$\begin{array}{l}\text { Sigara bıraktırma eğitimine } \\
\text { katıldınız mı? }\end{array}$} \\
\hline - Evet katıldım & 14 & 18.4 \\
\hline - Hayır katılmadım & 62 & 81.6 \\
\hline
\end{tabular}
sigara içmeyen ve \%21.4'ü sigara içmeyi bırakan gruplarında yer almaktadır. Buradan da anlaşılacağ1 gibi, diğer eğitim düzeylerinde yer alan olgulara göre, eğitim düzeyi yükseköğretim olan olgularda sigara içme oranı daha yüksekken, sigara içmeme oranı daha düşüktür. Bununla birlikte araştırma grubunda şehir merkezinde yaşayan olguların \%33.3'ü sigara içen, \%59.6's1 hiç sigara içmeyen, \%7.1'i ise sigara içmeyi bırakan durumundadır. Kasaba veya köyde yaşayanların ise \%37.0'si sigara içen, yine \%37.0'si hiç sigara içmeyen ve \%26.0'sı ise sigara içmeyi bırakan durumdadır. Buradan da anlaşılacağı gibi, şehir merkezine göre kasaba veya köyde yaşayan sporcu ve antrenörlerin daha düşük oranda sigara içmeme davranışı sergiledikleri ya da daha yüksek oranda sigara içme durumuna sahip oldukları, ancak daha yüksek oranda da 
sigara içmeyi bırakabildikleri gözlenmiştir. Ayrıca araştırma grubunda aile yanında ikamet eden sporcu ve antrenörlerden \%32.1'i halen sigara içen, \%61.3'ü hiç sigara içmeyen, \%6.6's1 ise sigara içmeyi bırakan olgular arasında yer almaktadır. İkamet durumu arkadaş yanı veya yurt olanların ise \%44.8'i halen sigara içen, \%27.6's hiç sigara içmeyen ve yine \%27.6'sı ise sigara içmeyi bırakan olgular arasındadır. Buna göre, ailesi ile birlikte kalanlarla karşılaştırıldığında arkadaş yanı veya yurtta ikamet eden sporcu ve antrenörlerin daha düşük oranda sigara içmeme davranışı sergiledikleri ya da daha yüksek oranda sigara içme alışkanlığına sahip oldukları, ancak daha fazla oranda da sigara içmeyi bıraktıkları tespit edilmiştir.

Tablo 4. Araştırma Grubunda Farklı Sosyo-Demografik Özelliklere Göre Sigara İçme Alışkanlığı

\begin{tabular}{|c|c|c|c|c|c|c|c|c|}
\hline & \multicolumn{6}{|c|}{ Sigara İçme Durumu } & & \\
\hline & \multicolumn{2}{|c|}{ Sigara İçenler } & \multicolumn{2}{|c|}{$\begin{array}{l}\text { Hiç Sigara } \\
\text { İçmeyenler }\end{array}$} & \multicolumn{2}{|c|}{$\begin{array}{l}\text { Sigara İçmeyi } \\
\text { Bırakanlar }\end{array}$} & \multicolumn{2}{|c|}{ Toplam } \\
\hline & $\mathbf{n}$ & $\%$ & $\mathbf{n}$ & $\%$ & $\mathbf{n}$ & $\%$ & $\mathbf{n}$ & $\%$ \\
\hline \multicolumn{9}{|l|}{ Cinsiyet } \\
\hline - Erkek & 56 & 36.4 & 86 & 55.8 & 12 & 7.8 & 154 & 68.4 \\
\hline - Kadın & 20 & 28.2 & 42 & 59.2 & 9 & 12.6 & 71 & 31.6 \\
\hline \multicolumn{9}{|l|}{$X^{2}=2.302 ; p=0.316$} \\
\hline \multicolumn{9}{|l|}{ Eğitim düzeyi } \\
\hline - İlköğretim & 8 & 27.6 & 15 & 51.7 & 6 & 20.7 & 29 & 12.9 \\
\hline - Lise & 56 & 33.3 & 103 & 61.3 & 9 & 5.4 & 168 & 74.7 \\
\hline - Yükseköğretim & 12 & 42.9 & 10 & 35.7 & 6 & 21.4 & 28 & 12.4 \\
\hline \multicolumn{9}{|l|}{$X^{2}=13.773 ; p=0.008$} \\
\hline \multicolumn{9}{|l|}{ Medeni durum } \\
\hline - Evli & 11 & 39.3 & 15 & 53.6 & 2 & 7.1 & 28 & 12.4 \\
\hline - Bekâr & 65 & 33.0 & 113 & 57.4 & 19 & 9.6 & 197 & 87.6 \\
\hline \multicolumn{9}{|l|}{$X^{2}=0.513 ; p=0.774$} \\
\hline \multicolumn{9}{|l|}{ Baba eğitim düzeyi } \\
\hline - İlköğretim & 38 & 29.0 & 81 & 61.8 & 12 & 9.2 & 131 & 58.2 \\
\hline - Lise & 25 & 35.7 & 38 & 54.3 & 7 & 10.0 & 70 & 31.1 \\
\hline - Yükseköğretim & 13 & 54.2 & 9 & 37.5 & 2 & 8.3 & 24 & 10.7 \\
\hline \multicolumn{9}{|l|}{$X^{2}=6.209 ; p=0.184$} \\
\hline \multicolumn{9}{|l|}{ Anne eğitim düzeyi } \\
\hline - İlköğretim & 51 & 32.2 & 96 & 60.8 & 11 & 7.0 & 158 & 70.2 \\
\hline - Lise & 17 & 33.3 & 26 & 51.0 & 8 & 15.7 & 51 & 22.7 \\
\hline - Yükseköğretim & 8 & 50.0 & 6 & 37.5 & 2 & 12.5 & 16 & 7.1 \\
\hline \multicolumn{9}{|l|}{$X^{2}=6.156 ; p=0.188$} \\
\hline \multicolumn{9}{|l|}{ Yaşam yeri } \\
\hline - Şehir merkezi & 66 & 33.3 & 118 & 59.6 & 14 & 7.1 & 198 & 88.0 \\
\hline - Kasaba veya köy & 10 & 37.0 & 10 & 37.0 & 7 & 26.0 & 27 & 12.0 \\
\hline \multicolumn{9}{|l|}{$X^{2}=11.272 ; p=0.004$} \\
\hline \multicolumn{9}{|l|}{ İkamet durumu } \\
\hline - Aile yanı & 63 & 32.1 & 120 & 61.3 & 13 & 6.6 & 196 & 87.1 \\
\hline - Arkadaş yanı veya yurt & 13 & 44.8 & 8 & 27.6 & 8 & 27.6 & 29 & 12.9 \\
\hline$X^{2}=18.112 ; p=0.000$ & & & & & & & & \\
\hline
\end{tabular}

Yukarıda Tablo 4'e ilişkin bulgular özetlenecek olursa; şehir merkezinde yaşayan, aileleri ile birlikte ikamet eden ve eğitim düzeyleri ilköğretim ve lise olan genç sporcu ve antrenörlerin diğerlerine göre daha az oranda sigara içme alışkanlığına sahip oldukları söylenebilir. Bir başka deyişle, şehir merkezi dışında yaşayan, arkadaş yanı veya yurtta ikamet eden, eğitim düzeyi yükseköğretim olan sporcu ve antrenörlerin daha yüksek oranda sigara içme alışkanlığına sahip 
olduğu, aynı zamanda diğerlerine göre daha yüksek oranda sigara içmeyi bıraktıkları gözlenmiştir.

Araştırma grubunu oluşturan genç sporcu ve antrenörlerin sigaraya ilişkin düşünce ve tutumlarına göre sigara içme alışkanlıkları Tablo 5'de sergilenmiştir.

Tablo 5. Araştırma Grubunda Sigaraya İlişkin Düşünce ve Tutumlara Göre Sigara İçme Alışkanlığ

\begin{tabular}{|c|c|c|c|c|c|c|c|c|}
\hline & \multicolumn{6}{|c|}{ Sigara İçme Durumu } & & \\
\hline & \multicolumn{2}{|c|}{ Sigara İçenler } & \multicolumn{2}{|c|}{$\begin{array}{l}\text { Hiç Sigara } \\
\text { İçmeyenler }\end{array}$} & \multicolumn{2}{|c|}{$\begin{array}{l}\text { Sigara İçmeyi } \\
\text { Birakanlar }\end{array}$} & \multicolumn{2}{|c|}{ Toplam } \\
\hline & $\mathbf{n}$ & $\%$ & n & $\%$ & $\mathbf{n}$ & $\%$ & $\mathbf{n}$ & $\%$ \\
\hline \multicolumn{9}{|l|}{$\begin{array}{l}\text { Sigaranın zararları ile ilgili bir } \\
\text { eğitime katıldınız mı? }\end{array}$} \\
\hline - Evet & 36 & 33.6 & 57 & 53.3 & 14 & 13.1 & 107 & 47.6 \\
\hline - Hayır & 40 & 33.9 & 71 & 60.2 & 7 & 5.9 & 118 & 52.4 \\
\hline \multicolumn{9}{|l|}{$X^{2}=3.546 ; p=0.170$} \\
\hline \multicolumn{9}{|l|}{$\begin{array}{l}\text { Sporcunun sigara içmesini nasıl } \\
\text { karşılarsınız? }\end{array}$} \\
\hline - Sporcu sigara içebilir & 27 & 58.7 & 15 & 32.6 & 4 & 8.7 & 46 & 20.4 \\
\hline - Sporcu sigara içmemelidir & 49 & 27.4 & 113 & 63.1 & 17 & 9.5 & 179 & 79.6 \\
\hline \multicolumn{9}{|l|}{$X^{2}=16.646 ; p=0.000$} \\
\hline \multicolumn{9}{|l|}{$\begin{array}{l}\text { Sigaranın zararları ile ilgili } \\
\text { eğitime ihtiyaç var mı? }\end{array}$} \\
\hline - Evet & 48 & 31.0 & 91 & 58.7 & 16 & 10.3 & 155 & 68.9 \\
\hline - Hayır & 28 & 40.0 & 37 & 52.9 & 5 & 7.1 & 70 & 31.1 \\
\hline \multicolumn{9}{|l|}{$X^{2}=1.977 ; p=0.372$} \\
\hline \multicolumn{9}{|l|}{$\begin{array}{l}\text { Sigara içmek performansı } \\
\text { olumsuz yönde etkiler mi? }\end{array}$} \\
\hline - Evet & 56 & 31.1 & 112 & 62.2 & 12 & 6.7 & 180 & 80.0 \\
\hline - Hayır & 20 & 44.4 & 16 & 35.6 & 9 & 20.0 & 45 & 20.0 \\
\hline \multicolumn{9}{|l|}{$X^{2}=13.252 ; p=0.001$} \\
\hline \multicolumn{9}{|l|}{$\begin{array}{l}\text { Sporcuların sigarayla ilgili } \\
\text { tutumlarından hangisi doğrudur }\end{array}$} \\
\hline $\begin{array}{l}\text { - Sporcu sigara içmeyerek iyi } \\
\text { örnek olmalıdır }\end{array}$ & 45 & 33.6 & 80 & 59.7 & 9 & 6.7 & 134 & 59.6 \\
\hline $\begin{array}{l}\text { - Sporcu sigara bırakmayla ilgili } \\
\text { eğitimlere katılmalıdır }\end{array}$ & 21 & 32.3 & 38 & 58.5 & 6 & 9.2 & 65 & 28.9 \\
\hline $\begin{array}{l}\text { - Sigara bırakma çalışmaları } \\
\text { sporcuların konusu değildir }\end{array}$ & 10 & 38.5 & 10 & 38.4 & 6 & 23.1 & 26 & 11.6 \\
\hline \multicolumn{9}{|l|}{$X^{2}=6.978 ; p=0.137$} \\
\hline \multicolumn{9}{|l|}{$\begin{array}{l}\text { Çevrenizdekileri sigara } \\
\text { içmemeleri konusunda uyarır } \\
\text { mısınız? }\end{array}$} \\
\hline - Daima uyarırım & 21 & 24.7 & 56 & 65.9 & 8 & 9.4 & 85 & 37.8 \\
\hline - Gerektiği zaman uyarırım & 26 & 34.7 & 42 & 56.0 & 7 & 9.3 & 75 & 33.3 \\
\hline - Kimseye karışmam & 29 & 44.6 & 30 & 46.2 & 6 & 9.2 & 65 & 28.9 \\
\hline$X^{2}=6.886 ; p=0.142$ & & & & & & & & \\
\hline
\end{tabular}

Tablo 5'de de görüldüğü gibi, sporcu sigara "içebilir" ya da "içmemelidir" görüşüne $\left(X^{2}=16.646 ; \mathrm{p}<0.05\right)$ ve sigara içmenin performansı olumsuz yönde "etkileyeceği" ya da "etkilemeyeceği” düşüncesine $\left(X^{2}=13.252 ; \mathrm{p}<0.05\right)$ göre araştırma grubunda sigara içme, sigara içmeme ve sigarayı bırakma davranışları anlamlı ölçüde değişmektedir. "Sporcunun sigara içmesini nasıl karşılarsınız?" sorusuna "sporcu sigara içebilir" şeklinde cevap veren olguların \%58.7’si sigara içenler grubunda, \%32.6's1 sigara içmeyenler grubunda, \%8.7’si ise sigara 
içmeyi bırakanlar grubundadır. Diğer taraftan aynı soruya "sporcu sigara içmemelidir" cevabını veren olguların ise sadece \%27.4'ü sigara içenler grubunda, \%63.1'i sigara içmeyenler grubunda, \%9.5'i ise sigara içmeyi bırakanlar grubunda yer almaktadır. Buradan da anlaşıldığı gibi sporcunun sigara içmemesi gerektiği görüşünü savunan sporcu ve antrenörlerde sigara içmeyen olguların oranı daha fazla iken (\%63.1), sporcunun sigara içebileceği görüşünde olan sporcu ve antrenörlerde sigara içen olguların oranı daha yüksektir (\%58.7) ve sporcu sigara "içebilir" ya da "içmemelidir" görüşüne göre sigara içme davranış1 anlamlı ölçüde değişmektedir $(p<0.05)$. Bununla birlikte, sigaranın performansı olumsuz yönde etkileyeceğini düşünen sporcu ve antrenörlerin \%31.1'i sigara içen grubunda, \%62.2'si sigara içmeyenler grubunda, \%6.7'si sigaray1 bırakanlar grubunda yer alırken, performansın sigaradan olumsuz yönde etkilenmeyeceğini düşünen sporcu ve antrenörlerin \%44.4'ü sigara içenler grubunda, \%35.6's1 sigara içmeyenler grubunda ve \%20.0'si ise sigarayı birakanlar grubunda yer almaktadır. Nitekim yukarıdaki bulgulardan da anlaşılacağı gibi, sigaranın performansı olumsuz yönde etkileyeceğini düşünen sporcu ve antrenörlerde hiç sigara içmeyen olguların oranı oldukça yüksek iken (\%62.2), halen sigara içen olguların oranı daha düşüktür $(\% 31.1)$ ve sigara içmenin performansı olumsuz yönde "etkileyeceğì" ya da "etkilemeyeceğ $i$ " düşüncesine göre sigara içme davranışı anlamlı ölçüde değişmektedir $(\mathrm{p}<0.05)$.

Diğer taraftan araştırma grubundaki sporcu ve antrenörlerde sigara içme, sigara içmeme ve sigarayı bırakma davranışları, sigaranın zararları ile ilgili bir eğitime katılıp katılmamaya $\left(X^{2}=3.546 ; \mathrm{p}>0.05\right)$, sigaranın zararları ile ilgili eğitime ihtiyaç duyup duymamaya $\left(X^{2}=1.977\right.$; $\mathrm{p}>0.05)$, sporcuların sigarayla ilgili farklı tutumlarına $\left(X^{2}=6.978 ; \mathrm{p}>0.05\right)$ ve çevredekileri sigara içmeye karşı uyarıp uyarmamaya $\left(X^{2}=6.886\right.$; $\left.\mathrm{p}>0.05\right)$ göre anlamlı ölçüde değişkenlik göstermemektedir. Ancak istatistiksel olarak anlamlı ölçüde farklılık olmamakla birlikte tablo 5 incelendiğinde, sporcu sigara içmeyerek iyi örnek olmalıdır düşüncesine sahip olan sporcu ve antrenörlerin \%59.7'si sigara içmeyenler grubunda yer alırken, halen sigara içenler grubunda bu düşünceyi destekleyenlerin oranı sadece \%33.6'dır. Yine buna benzer şekilde sporcu sigaray1 bırakmayla ilgili eğitimlere katılmalıdır görüşüne sahip olan sporcu ve antrenörlerin \%58.5’i sigara içmeyen olgular arasında yer alırken, halen sigara içen olgular arasında bu görüşü savunanların oranı sadece \%32.3 düzeyindedir. Bununla birlikte çevredekileri sigara içmemeleri konusunda daima uyaran sporcu ve antrenörlerin \%65.9'u sigara içmeyen olgular arasında yer alırken, halen sigara içen olgular arasında bu tutumu sergileyenlerin oranı sadece \%24.7 düzeyindedir.

Araştırma grubunda sigaraya ilişkin düşünce ve tutumların sigara içme alışkanlığg üzerindeki etkileri özetlenecek olursa; sporcunun sigara içmemesi gerektiğini düşünen, çevredekileri bu yönde daima uyaran ve sigara içmenin performansı olumsuz yönde etkileyeceği görüşünde olan sporcu ve antrenörlerin diğerlerine göre daha düşük oranda sigara içme davranışı sergilediği tespit edilmiştir. Ancak sporcunun sigara içebileceği görüşünde olan, kimseye sigara içme konusunda karışmayan ve en önemlisi sigara içmenin fiziksel performansı olumsuz yönde etkilemeyeceğini düşünen genç sporcu ve antrenörler daha fazla oranda sigara içme davranışına sahiptirler.

\section{Tartışma ve Sonuç}

Yarışmacı olarak spor yapan gençler ve toplumda önemli rol model görevi olan antrenörlerin sigara içme konusunda tutum ve davranışlarının farklı değişkenlere göre değerlendirildiği bu çalışmada, genç sporcu popülasyonunda sigara içme oranı \%33.8 olarak bulunmuştur. Bu oranın farklı ülkelerde çeşitli spor dallarındaki sporcularla yapılan benzer araştırma sonuçlarında elde edilen sigara içme oranlarından daha yüksek olduğu söylenebilir (Hessami 2012; Pacifici 2016). 
$\mathrm{Bu}$ araştırmada sigara içen sporcu ve antrenörlerin sigaraya başlama yaş ortalamaları sırasıyla $13.8 \pm 2.4$ yıl ve $18.0 \pm 5.2$ yıl olarak tespit edilmiştir. Genel olarak araştırma grubunda sigaraya başlama yaşı ortalaması $14.6 \pm 3.3$ yıldır. Özellikle genç sporcularda sigara içmeye başlama yaşının $13.8 \pm 2.4$ yıl gibi oldukça düşük bir yaş ortalaması olması dikkat çekmektedir. Oysaki sigaraya erken yaşta başlamada sosyal çevre, özenti, bilgi eksikliği ve merak gibi önlenebilir sebeplerin etkili olduğu bilinmektedir (Sağlam 2000). Bu çalışmada, araştırma grubunda yer alan ve halen sigara içen olguların sadece \%40.8'i günde 1 ile 10 adet arasında sigara içmekte, geriye kalan \%59.2'si ise günde 10 adetten fazla sayıda sigara tüketmektedir. Ayrıca, sigara içenlerden \%81.6'sının en az 2 yıl ve daha uzun süredir sigara içmeye devam ettiği belirlenmiştir. Sigara içen genç sporcu popülasyonun \%27.6'sının en az 8 yıl veya daha uzun süredir sigara içme alışkanlığını devam ettirdikleri ve \%59.2'sinin bu alışkanlığa spora başlamadan önce yakalandıkları tespit edilmiştir. Ayrıca, sigara içenlerden \%56.6'sının yasak olan yerlerde sigara içmenin zor olmayacağını belirtmesi ve \%72.4'ünün sigara bittiğinde arkadaşlarından sigara istediğini belirtmiş olması, sigara bağımlılığının genç sporcu popülasyonunda ne denli yüksek boyutta olduğunu göstermesi açısından önemlidir.

Sigara içme alışkanlığı büyük oranda 15-19 yaşlarında başlayan önemli bir psiko-sosyal halk sağlığı sorunudur. Tüm dünyada ve ülkemizde 15 yaşın üzerindeki nüfusun yaklaşık yarısının sigara bağımlısı olması insanlığın ne derece tehlikede olduğunun bir göstergesidir. Dünya Sağlık Örgütü verilerine göre toplumlardaki sigara içme oranı gelişmiş ülkelerde azalma eğilimi gösterirken, bizim gibi gelişmekte olan ülkelerde artan bir eğilim içerisindedir. Dünyada sigara içme sıklığındaki artış yıllık \%7.0 iken, ülkemizde bu oran yıllık \%10.0 civarındadır (Pekşen 1995; Chapman 2008).

$\mathrm{Bu}$ çalışmada araştırma grubunu oluşturan genç sporcu popülasyonunun \%33.8'inin halen sigara içtiği ve bunların \%68.4'ünün erkek, \%31.6'sının kadın olduğu belirlenmiştir. Aynı zamanda halen sigara içenlerin \%81.6'sının alışkanlığı en az 2 yıl ve daha uzun süredir devam etmektedir. Ülkemizde genel popülasyonda sigara içme sıklığ 2012 yılında ortalama \%23.2 (erkeklerde; \%35.9, kadınlarda; \%10.8), 2014 y1lında ise ortalama \%27.3 (erkeklerde; \%41.8, kadınlarda; \%13.1) olarak bildirilmiştir (Sağlik İstatistikleri 2015). Dünya ülkelerinde ise bu oranların yetişkin erkeler için \%40.0, yetişkin kadınlar için ise \%9.0 olduğu belirtilmektedir (Aslan \& Özen 2015). Yukarıdaki bu oranların genel popülasyondaki sigara içme sıklığını yansıttığı dikkate alındığında, bu çalışmada değerlendirilen genç sporcu popülasyonunda sigara içme oranının \%33.8 olması oldukça düşündürücü ve olumsuz bir durumdur. Diğer taraftan sigara içen olgularda erkeklerin, kadınlara göre daha yüksek oranda tespit edilmesi, literatürdeki dağglımlarla uyum sergilemektedir.

İtalyan sporcularda nikotin, kotinin ve trans-3-hidroksi-kotinin değeri ölçülümü ile sigara içme alışkanlığının değerlendirildiği bir çalışmada, sigara içme sıklığının özellikle futbol, buz hokeyi gibi takım sporlarıyla uğraşan sporcularda daha yaygın olduğu gösterilmiştir. Sürekli olarak Dünya Anti Doping Kuruluşu kontrolünde olan ve 38 farklı spor dalında yarışan bu sporcularda, aktif olarak sigara içme sıklığının genel toplamda \%18.7 (erkeklerde; \%17.9, kadınlarda; \%20.7) oranında olduğu gösterilmiştir. Sporcularda sigara içme sıklığının en düşük \%4.7 oranıyla bisikletçilerde, en yüksek \%53.1 oranıyla futbolcularda olduğu belirtilmiştir (Pacifici 2016). Amatör tenisçilerle yapılan bir başka araştırmada ise, sigara içme oranının \%25.4 olarak saptandığı bildirilmektedir (Arıkan \& Şanlıer 2006). Literatürdeki bu bulgulardan da anlaşılacağ gibi, bu çalışmada değerlendirilen genç sporcu popülasyonuna ilişkin olarak gözlenen sigara içme sıklı̆̆ oldukça yüksektir.

Diğer taraftan, literatürde sigara içme alışkanlığı ile ilgili olarak halter spor dalını ele alan 
herhangi bir araştırma bulunmamaktadır. Bu çalışma bu yönü ile bir ilktir. Bireysel bir spor dalı olan halter ile uğraşan genç sporcu ve antrenörlerin değerlendirildiği bu çalışmada, genç sporcu popülasyonun sigara içme oranının ülkemizde genel popülasyondan elde edilen 2012 ve 2014 yılı sigara içme oranlarından bile yüksek olduğu gözlenmiştir. Bu durum sporcular arasında sigara içme alışkanlığının yayılan bir hastalık olma yolunda hızla ilerlediğini göstermektedir. Sporcularda sigara içme alışkanlığını önlemek için derhal köklü önlemler alınması ve bu kötü alışkanlığın yayılmasının önüne geçmek için toplumun tüm kesimleriyle duyarlı davranması gerekmektedir.

Sigara içme alışkanlığını kazanmada sosyal öğrenmenin katkısı büyüktür. Sigaraya başlamanın önüne geçilmesi ve sigarayı bırakmanın özendirilmesinde gençlerin rol model aldıkları kişilerin gençleri teşvik edici tarzda sigara kullanmamaları ve içiyorlarsa sigarayı bırakmalarının gençler üzerinde büyük oranda etkisi olduğu bilinmektedir (Herken 2000). Çalışmamıza katılan antrenörlerin kendi içerisinde sigara içme sıklığı oldukça yüksek orandadır. Sporcularda antrenörlerinin doğru davrandıkları yönünde yaygın bir kanı vardır. Özellikle antrenörlerin sağlıkla ilgili davranışları sporcular tarafından yakından izlenir. Antrenörler sağlıklı davranmaya özen göstermelidir. Çünkü sporcular antrenörlerini sağlik dâhil pek çok konuda rol model kabul ederler. $\mathrm{Bu}$ nedenle başta antrenörler olmak üzere ebeveyn ve öğretmenler gibi rol model olan herkes sigara içmeyerek genç sporculara iyi örnek olmalıdırlar.

$\mathrm{Bu}$ çalışmada, sigara içen genç sporcu popülasyonunun \%61.8'i sigarayı bırakmak istediğini, ancak \%51.3’ü sigarayı bırakabileceğini düşünmediğini belirtmiştir. Yine sigara içen olguların \%63.2'sinin sigarayı bırakmayı denedikleri ancak bunda başarılı olamadıkları ve \%81.6'sının ise sigara bıraktırma eğitimine katılmadıkları dikkate alındığında, gelecekte genç sporcu ve antrenörlere uygulanacak olan sigara bıraktırma eğitimi programlarının ne kadar önemli olabileceği görülmektedir. Sigaraya başlama yaşının $18.7 \pm 4.2$ y1l olarak bulunduğu diğer bir çalışmada, sigara içenlerin \%67.5'inin ömründe en az bir kez sigarayı bırakmayı denediği, ancak bunda başarılı olamadığı ifade edilmiştir (Atılgan, Gürkan \& Şen 2008). Başka bir çalışmada ise, sigara içenlerin \%69.4'ünün ömründe en az bir kez sigarayı bırakmayı denediği ve başarılı olamadığı, \%48.1'inin ise en az bir kez sigarayı bıraktığı gösterilmiştir (Öncel 1994). Bu çalışmada sigara içen genç sporcu ve antrenörlerden \%61.8'inin sigarayı birakmak istediği ve \%63.2'sinin ise sigarayı bırakmayı denediği ancak bunda başarılı olamadığı tespit edilmiştir. Yukarıda belirtilen literatür bilgileri ile uyumlu olan bu bulgulara göre, sigara alışkanlığı olan genç sporcu ve antrenörlerin yüksek oranda bu alışkanlıktan kurtulmak istedikleri anlaşılmaktadır.

Ebeveynlerin sigara alışkanlığı, sosyal çevre, medeni durum, öğrenim durumu, ikamet edilen yer ve yaşam yeri gibi pek çok etken, genç bireylerin sigara içme alışkanlığı kazanmasında önemli yere sahiptir (Atılgan, Gürkan \& Şen 2008). Bu çalışmada, arkadaş yanı veya yurtta ikamet eden, eğitim düzeyi yükseköğretim olan, şehir merkezi dışında yaşayan genç sporcu ve antrenörlerin daha yüksek oranda sigara içme alışkanlığına sahip olduğu, aynı zamanda daha yüksek oranda sigara içmeyi bıraktığı gözlenmiştir. Bu bulgular dikkate alındığında, sigaraya başlama yaşının oldukça düşük olduğu örneklemimizi oluşturan ergenlik çağındaki genç sporcularda, kötü alışkanlıkların kazanılması ya da bu durumun engellenmesinde sosyal çevrenin, arkadaşl1k ilişkilerinin ve yaşam yerinin önemli oranda etkisinin olduğu söylenebilir.

Sigara içmek önlenebilir bir alışkanlık olmasına rağmen, sigara içmenin sporcunun solunum ve kalp-dolaşım sistemlerinde son derece yıkıcı hasarlara sebep olduğu ve sporcu performansını olumsuz yönde etkilediği iyi bilinen bir gerçektir. Yaşamsal açıdan tehlikeli olan bu kötü alışkanlık, sporcuyuda giderek spordan uzaklaştırmaktadır (Chapman 2008; Feinberg 2015). Ayrıca, si- 
gara içme alışkanlığı insan vücudunda uzun dönemde mikrovasküler fonksiyonları bozarak hayatı ve yaşam kalitesini tehdit eden birçok ölümcül hastalığa yol açmaktadır (Çiftçi 2013). Genellikle yüksek yoğunlukta statik egzersizin baskın olduğu halter gibi ağırlık kaldırma sporlarında anaerobik performans etkindir (Mitchell 2005). Sigara içme alışkanlığı olan sporcularda hem aerobik hem de anaerobik performans olumsuz etkilenir (Fubuka 1993). Bu çalışmada, sporcunun sigara içmemesi gerektiğini düşünen, çevredekileri bu yönde daima uyaran ve sigara içmenin performansı olumsuz yönde etkileyeceği görüşünde olan olguların daha düşük oranda sigara içme davranışı sergilediği tespit edilmiştir. Ancak sporcunun sigara içebileceği görüşünde olan, kimseye sigara içme konusunda karışmayan ve en önemlisi sigara içmenin fiziksel performansı olumsuz yönde etkilemeyeceğini düşünen olgular daha fazla oranda sigara içme davranışına sahiptirler. Bu bulgulara göre; kendilerinden madalya beklenen fakat halen sigara içen genç sporcuların sigara içmenin zararlarını henüz tam olarak anlayamadıkları, eğitim ve profesyonel destekle sigara alışkanlığından vazgeçirilmeleri gerektiği ve sigaranın performans üzerindeki olumsuz etkilerinin daha iyi anlatılması gerektiği sonuçları çıkarılabilir.

Sigara içme alışkanlığı, temelinde davranışsal, psikolojik ve fiziksel bağımlılığın rol oynadığı önlenebilir kötü bir bağımlılıktır (Uzaslan 2003). Sigara içme alışkanlığıyla mücadele etmenin temelini; insanların sigara içmeye karşı dayanıklı hale getirilmesi, sigara içmeye başlamanın önlenmesi gibi önleyici tedbirlerle birlikte, halihazırda sigara içenlerin bırakmalarının sağlanması oluşturur. Eğer bir kere sigara içme alışkanlığı başlamış ise, sigara bıraktırmada en önemli mücadele konusu nikotin bağımlılığının aşılabilmesidir (Uzaslan 2003; Karlıkaya 2006).

Sigara içme alışkanlığının sonlandırılması için iki etkili bilimsel tedavi yaklaşımı geliştirilmiştir. Bunlardan birisi, bilişsel-davranışçı yaklaşımlarla motivasyondan oluşan destek tedavisi, diğeri ise ilaç tedavisidir. Her iki yöntemin de tek başına uygulanmasının etkili olabileceği, ancak iki yöntemin birlikte uygulanmasının sigarayı bırakma oranlarını daha fazla artıracağı bildirilmektedir. Sigara bırakma tedavisi süresince profesyonel sağlık görevlisi ile yoğun ve etkin görüşmeler motivasyonu sağladığı için tedavinin etkinliğini artırmaktadır. Özellikle bilişseldavranışçı yöntem; hasta eğitimi, bireysel ya da grup terapileri, tiksindirme, psikoterapi, hipnoz, transandantal meditasyon, desensitizasyon ve duygusal deprivasyon gibi önemli bileşenleri kapsar (Fiore 2000; Uzaslan 2003).

Sigarayı bırakmak isteyen ve ilaç kullanmasına herhangi bir engeli olmayan her bağımlı için birinci basamak olarak ilaç tedavisi uygulanmalıdır. İlaç tedavisi uzun süreli sigara bırakmayı önemli derecede artırmaktadır. Birinci basamak ilaçlar; nikotin replasman tedavisi (bant, sakız, inhaler, nazal sprey) ve bupropion'dur. Etkili olduğu gözlenen birinci basamak ilaç tedavisi yetersiz kaldığında ikinci basamakta ilaç tedavisi olarak clonidine ve nortriptyline kullanılmalıdır. Sigara bırakma tedavisinde taklit sigara ve bitkisel ile kimyasal ürünlerin etkinliği gösterilmemiştir (Karlıkaya 2006). Diğer taraftan, akupunktur, lazer tedavisi veya elektriksel uyar1nın sigara alışkanlığını uzun süreli olarak bırakmada çok etkili olmadığı bildirilmektedir (Tür 1995; White, Rampes \& Ernst 2005).

Hekimlerde sigara içme davranışının incelendiği bir çalışmada, sigarayı bırakmada en etkili yöntem olarak \%36.9 oranında "aniden bırakma" yönteminin tercih edildiği bildirilmektedir (Özyurt 2006). Bu çalışmada, araştırma grubunu oluşturan genç sporcu ve antrenörler en etkili sigara bırakma yöntemi olarak ilk sırada \%28.9 oranında "azaltarak bırakma" yöntemini, ikinci sırada ise \%16.0 oranında "nikotin yerine koyma" yöntemini gördüklerini belirtmişler, ancak araştırma grubunun \%17.8'i ise en etkili sigara bırakma yöntemi konusunda herhangi bir fikrinin olmadığını belirtmiştir. Oysaki sigarayı azaltarak bırakma yöntemi, nikotinin kandaki düzeyinin eşik değerin altına düşmesine ve nikotinin yoksunluk belirtilerine sebep olur. Bu 
durum bireyin stresten dolayı eski alışkanlığa dönmesine neden olabilmektedir. Fakat sigaranın "aniden birakılması" yöntemi, ilk haftalarda bazı sıkıntılara sebep olmasına rağmen bu durum aşılabilirse, bireyin yeniden sigaraya başlama oranı açısından "azaltarak bırakma" yöntemine göre daha etkilidir (Uzaslan 2003). Sigara bırakmada etkin yönteminin bilinmesi açısından literatürden farklı olan bu bulgular, genç sporcu ve antrenörlerde sigara bırakma yöntemleri konusunda bilgi eksikliği ve yanlışlıklar olduğunun göstergesidir.

Yukarıdaki bulgulardan da anlaşılacağ 1 gibi, kendilerinden madalya beklentisi olan, toplumda lider konumundaki genç sporcu ve antrenörlerde sigara içme alışkanlığ ciddi bir toplum sağlığı sorunu olarak giderek yaygınlaşmaktadır. Gelişmiş ülkelerde genel popülâsyona ve sporculara yönelik olarak uygulanan tütün kontrol programlarının etkili olduğu bilinmektedir. Sporculara öncelikle sigaraya başlamamaları için her türlü destek sağlanmalı, uygun ortam ve sosyal çevre oluşturulmalı ve başlamış olanların ise bıraktırılması için bilgilendirici, özendirici, eğitim ve motivasyon etkinlikleri yapılmalıdır. Sporcularla etkili iletişim kurulmalı ve sporcular yakından takip edilmelidir. Özellikle önemli rol model görevi olan antrenör, öğretmen ve ebeveynlerden sigara içenlerin derhal sigarayı bırakmaları, sigara içen sporcularda bıraktırma motivasyonu oluşturulmalı ve bırakma oranını artırıcı davranışsal ve tıbbi tedavi olanakları seferber edilmelidir.

Sonuç olarak, Türkiye Gençler Halter Şampiyonasında yarışan ve bu araştırmaya katılan genç sporcu ve antrenörlerde sigara içme sıklığ 1 (\%33.8), ülkemiz ve dünyadaki genel oranlardan oldukça yüksektir. Özellikle genç sporcularda sigara içmeye başlama yaşı (13.8 \pm 2.4 yıl) oldukça düşüktür. $\mathrm{Bu}$ çalışma örnekleminde sigaraya başlama yaşı, literatürde farklı spor dallarındaki sporcularda gözlenen değerlerden ve genel popülasyondaki sigaraya başlama yaşı değerlerinden daha aşağıdadır. Sigara içen olgulardan \%59.2'sinin günde 10 adetten fazla sayıda sigara içtiği ve \%81.6'sının en az 2 yıl ve daha uzun süredir sigara içme alışkanlığı olduğu belirlenmiştir. Sigara içen sporcu ve antrenörlerin \%59.2'sinin bu alışkanlığa spora başlamadan önce yakalanmış olduğu tespit edilmiştir. Sigara içen olguların \%61.8'inin sigarayı bırakmak isteği, \%63.2'sinin bırakmayı denediği ancak başaramadığ1 ve \%81.6'sının herhangi bir bıraktırma eğitimine katılmadığı saptanmıştır. Ayrıca araştırma grubunu oluşturan olguların en etkili sigara bırakma yöntemi olarak ilk sırada \%28.9 oranında "azaltarak bırakma" yöntemini gördükleri, \%17.8’inin bırakma yöntemi konusunda fikrinin olmadığı belirlenmiştir. Bu sonuçlar, sigara içen genç sporcu popülasyonunun sigarayı bırakmak istediğini, ancak bu konuda bilgili olmadığını ve genç sporculara yönelik olarak sigara bıraktırma eğitiminin ne kadar önemli olabileceğini göstermektedir. Bununla birlikte, sporcunun sigara içebileceği görüşünde olan, kimseye sigara içme konusunda karışmayan ve en önemlisi sigara içmenin fiziksel performansı olumsuz yönde etkilemeyeceğini düşünen olguların daha fazla oranda sigara içme davranışı sergiledikleri tespit edilmiştir. Özellikle sigaranın fiziksel performans üzerindeki olumsuz etkileri genç sporcu ve antrenörlere daha iyi anlatılmalıdır. Sigara ile mücadelede, profesyonel sağlık ekipleri tarafindan periyodik aralıklarla sigara bırakma eğitim ve danışmanlıkları etkili bir şekilde verilmeli ve bu etkinliklerin başarısı izlenmeli, bağımlılık düzeylerine göre sporcular sigara bırakma merkezlerine yönlendirilmelidir. Çağdaş toplumda spor birimlerinin sigarasız olması vazgeçilmezdir ve sporcular bu konuda daha etkin ve duyarlı olmalıdır. 


\section{KAYNAKÇA}

Alışkın O., Savaş N., İnandı T., Peker E., Erdem M. \& Yeniçeri A. (2015). "Mustafa Kemal Üniversitesi Tıp Fakültesi Hastanesi Sağlık Personelinin Sigara İçme ve Bağımlılık Durumu". Mustafa Kemal Üniversitesi Tip Dergisi 24/6 (2015) 32-42.

Arıkan B. \& Şanlıer N. (2006). "Amatör Tenisçilerin Beslenme Durumlarının ve Bazı Antropometrik Ölçümlerinin Saptanması". 9. Uluslararası Spor Bilimleri Kongresi Bildiri Kitabı (3-5 Kasım 2006). (2006) 428-431.

Aslan D. \& Özen A. (2015). "Global Tobacco Use among Women and Details in Struggle”. Sted Journal of Continuing Medical Education 24 (2015) 6-9.

Aşut Ö. (1993). Hekim ve Sigara. Ankara 1993.

Atılgan Y., Gürkan S. \& Şen E. (2008). "Hastanemizde Çalı̧̧an Personelin Sigara İçme Durumu ve Etkileyen Faktörler”. Türk Toraks Dergisi 9/4 (2008) 160-166.

Behr J. \& Nowak D. (2002). “Tobacco Smoke and Respiratory Disease”. Ed. G. D’Amato \& S. T. Holgate. The Impact of Air Pollution on Respiratory Health (2002) 161-180.

Breslau N. \& Peterson E. L. (1996). "Smoking Cessation in Young Adults: Age at Initiation of Cigarette Smoking and Other Suspected Influences". American Journal of Public Health 86/2 (1996) 214-220.

Chapman S. (2008). Public Health Advocacy and Tobacco Control: Making Smoking History. Oxford 2008.

Çiftçi O., Günday M., Çalışkan M., Güllü H., Güven A. \& Müderrisoğlu H. (2013). "Light Cigarette Smoking and Vascular Function”. Acta Cardiologica 68 (2013) 255-261.

Erbaycu A. E., Aksel N., Çakan A. \& Özsöz A. (2004). "İzmir İlinde Sağlık Çalışanlarının Sigara İçme Alışkanlıkları". Toraks Dergisi 5/1 (2004) 6-12.

Feinberg J. H., Ryan M. A., Johns M., Marvin B. A., Reading J. E. \& White M. R. (2015). "Smoking Cessation and Improvement in Physical Performance Among Young Men”. Military Medicine 180/3 (2015) 343-349.

Fiore M. C. (2000). "US Public Health Service Clinical Practice Guideline: Treating Tobacco Use and Dependence”. Respiratory Care 45/10 (2000) 1200-1262.

Fubuka Y., Takamoto N., Kushima K., Ohtaki M., Kihara H., Tanaka T., Une S. \& Munaka M. (1993). “Cigarette Smoking and Physical Fitness”. Annual Physiology Anthropology 12/4 (1993) 195-212.

Herken H., Özkan İ., Çilli A. S., Telcioğlu M. \& Kucur R. (2000). "Sigara Kullanma Davranışında Sosyal Öğrenmenin Etkisi”. Bağımlılık Dergisi 1/1 (2000) 38-42.

Hessami Z., Aryanpur M., Emami H. \& Masjedi M. (2012). "Behavior and Knowledge of Iranian Professional Athletes towards Smoking”. Asian Journal of Sports Medicine 3/4 (2012) 297-300.

Kanıt L. \& Keser A. (2010). "Tütün Bağımlılığının Biyofizyolojisi”. Eds. Z. A. Aytemur, Ş. Akcay \& O. Elbek, Tütün ve Tütün Kontrolü (2010) 141-156.

Karlıkaya C., Öztuna F., Solak Z. A., Özkan M. \& Örsel O. (2006). “Tütün Kontrolü”. Toraks Dergisi 7/1 (2006) 51-64.

Mitchell J. H., Haskell W., Snell P. \& Van Camp S. P. (2005). "Task Force 8: Classification of Sports”. Journal of the American College of Cardiology 45/8 (2005) 1364-1367.

Öncel S. (1994). "İzmir Metropolünde Çalışan Sağlık Personelinin Sigara Konusundaki Tutum ve Davranışları”. IV. Ulusal Halk Sağllğı Kongresi Bildiri Kitabı (12-16 Eylül 1994). 671-673.

Öztürk Ö. (2009). "Sağlık Çalışanları ve Sigara”. Süleyman Demirel Üniversitesi Tip Fakültesi Dergisi 16/2 (2009) 32-38.

Özyurt L. (2006). Hekimlerin Sigara İ̧̧me Davranışlarının Bazı Değişkenler Açısından Değerlendirilmesi (Gazi Üniversitesi Tip Fakültesi Örneği). Yayımlanmamış Yüksek Lisans Tezi. Gazi Üniversitesi, Ankara 2006.

Pacifici R., Pichini S., Palmi I., Torre X. \& Botrè F. (2016). "Smoking Habits of Italian Athletes Undergoing Anti-Doping Control”. Drug Testing and Analysis 8/1 (2016) 133-135.

Pekşen Y. (1995). "Sigara İçiminin Nedenleri, Epidemiyolojisi, Pasif İçicilik". Ed. A. Tür, Sigaranın Sağllğa Etkileri ve Bırakma Yöntemleri (1995) 29-53. Samsun. 
Peto R. (1994). “Smoking and Death: The Past 40 Years and The Next 40”. British Medical Journal 309 (1994) 937-939.

Sağlam L., Kaynar H., Görgüner M. \& Mirici A. (2000). "Erzurum İlinde Sigara İçme Alışkanlığının Araştırılması". Solunum Hastalıkları Dergisi 11 (2000) 148-153.

Sezer R. E., Marakoğlu K., Sezer H. \& Marakoğlu İ. (2001). "Cumhuriyet Üniversitesi Tip ve Dişhekimliği Fakülteleri Öğretim Elemanlarının Sigara Kullanım Durumu ve Sigara ile Bağlantılı Görüşleri”. Cumhuriyet Üniversitesi Tip Fakültesi Dergisi 23/1 (2001) 25-36.

Tür A. (1995). "Sigarayı Bırakma Yöntemleri”. Ed. A. Tür, Sigaranın Sağllğa Etkileri ve Bırakma Yöntemleri (1995) 194-209. Samsun.

Uzaslan E. (2003). "Sigarayı Bırakma Yöntemleri”. Sted Journal of Continuing Medical Education 12/5 (2003) 166-171.

White A. R., Rampes H. \& Ernst E. (2005). “Acupuncture for Smoking Cessation (Review)”. The Cochrane Library 4 (2005) 1-32.

\section{İnternet Erişimleri}

Ash Smoking Statistics Illness and Death. (2016, June). Kaynak: http://ash.org.uk/files/documents/ ASH_107.pdf

Sağlık İstatistikleri. (n.d.). Insaglikistatistikleri.gov.tr. (2016, Aralık 22) Kaynak: http://www.saglik istatistikleri.gov.tr/dosyalar/SIY2015.pdf. 